\title{
ИНТЕГРАЦИЯ ГУМАНИТАРНЫХ НАУК В МЕЖПРЕДМЕТНУЮ ПРОГРАММУ В СРЕДНЕЙ ШКОЛЕ
}

\section{Боровикова Екатерина Викторовна}

\begin{abstract}
Аннотация: статья посвящена проблеме интеграции дисциплин литературы, истории, обществознания, искусствоведения в единый гуманитарный предмет, рассматривается предпосылки к новому подходу в образовательных программах, а также обосновывается очевидность данного объединения с практической и экономической точки зрения, приводятся наглядные примеры.
\end{abstract}

Ключевые слова: интеграция, дисциплина, гуманитарные науки, литература, история, обществознание, оптимизация, образование.

\section{INTEGRATION OF HUMANITIES INTO THE INTERDISCIPLINARY PROGRAM IN SECONDARY SCHOOL}

\section{Borovikova Ekaterina Viktorovna}

\begin{abstract}
The article is devoted to the problem of integrating the disciplines of literature, history, social studies, art history into a single humanitarian subject, examines the prerequisites for a new approach in educational programs, and also substantiates the evidence of this association from a practical and economic point of view, provides illustrative examples.

Key words: integrating, disciplines, humanities, literature, history, social studies, optimization, education.

Роман-эпопея «Тихий Дон» Михаила Александровича Шолохова в 1965 году получил Нобелевскую премию в номинации «Литература» за художественную силу и цельность эпоса о донском казачестве в переломное для России время [1, с. 290]. Это не первая премия в области литературы, присужденная советским писателям, но именно она заставляет задуматься о неразрывной связи и необходимости объединения таких дисциплин как история, обществознание, искусствоведение и литература. Это должен быть единый, цельный предмет.
\end{abstract}


Если про актуальность изучения истории и обществознания серьезных предубеждений нет, то изучение литературы как предмет вызывает как у подростков, так и у старшего поколения непонимание, и его все чаще воспринимают как факультативный. Большинство учеников изучают художественные произведения в кратком изложении, не обращаясь к оригинальному тексту. Многие не посещают уроки литературы.

Bсе это происходит в большей степени из-за отсутствия понимания практической значимости знаний, которые дает нам данный предмет.

Человек до достижения зрелости (а именно, совершеннолетия) находится в состоянии обучения, он не имеет достаточного опыта, должного уровня критического мышления для полноценной жизни в обществе. Тут и приходит на помощь литература, предметом которой являются художественные произведения, возведенные в разряд классики. Здесь достаточно шаблонные, жизненные ситуации предлагается рассмотреть с разных сторон. Моделируются ситуации, в которые в той или иной степени может попасть любой человек и в наше время. Перенеся опыт, показанный и разобранный на уроках литературы, ученик выйдет во взрослую жизнь уже с четкими представлениями о поведенческих нормах, гуманности и нравственности, и это, возможно, поможет ему не совершать ошибок.

Это один из аспектов изучения в художественной литературе. Но есть и другие. В программе по литературе достаточно примеров произведений, носящих явно историческое значение. Так, например, в «Капитанской дочке» А.С. Пушкина описывается Пугачевский бунт, «Борис Годунов» сам за себя говорит, «Кому на Руси жить хорошо?» описывает жизнь в период отмены крепостного права, «Слово о Полку Игореве» повествует о неудачном походе князя Игоря на половцев.

При изучении этих произведений учителя сталкиваются с проблемой отсутствия знаний эпохи, в которой происходит событие, ведущих исторических персон, которые оставили свой след в истории. Изучение данного рода произведений происходит обособленно от изучения истории России. Хотя под призмой художественно-исторических произведений классики возможно более глубокое, детальное рассмотрение культовых событий в истории.

Программы по литературе и истории не совпадают, что приводит к затруднению понимания темы, либо повторного ее рассмотрения, что снижает эффективность образования. 
Внедрение уроков-конференций, рассчитанных на два академических часа, где конкретное событие будет рассмотрено как с точки зрения исторической значимости, так и с точки зрения описания его в художественной литературы, а так же проблем, освещаемых обществознанием и искусствоведением, позволит погрузиться в исторический период, детально рассмотреть его с точки зрения научных фактов, увидеть события глазами авторов художественных произведений, прочувствовать настроения, ходившие в народе в той эпохе.

Параллельно необходимо проводить подобные уроки по всеобщей истории и зарубежной литературе.

Данная методика преподавания призвана скомпоновать разрозненные знания и максимально оптимизировать процесс усвоения этих дисциплин.

В таблице 1 приведены примеры объединения тем по предложенным дисциплинам в единый гуманитарный урок. По такому принципу необходимо построить всю рабочую программу.

Таблица 1

Примеры объединения по темам в гуманитарный урок

\begin{tabular}{|c|l|l|l|}
\hline $\begin{array}{c}\text { Предметы, } \\
\text { классы }\end{array}$ & \multicolumn{1}{|c|}{ Литература } & \multicolumn{1}{|c|}{ История } & \multicolumn{1}{|c|}{ Обществознание } \\
\hline 5 класс & $\begin{array}{l}\text { Мифы древних } \\
\text { славян }\end{array}$ & $\begin{array}{l}\text { Происхождение и } \\
\text { расселение славян }\end{array}$ & - \\
\hline 6 класс & $\begin{array}{l}\text { Древнерусская } \\
\text { литература, } \\
\text { «Повесть временных } \\
\text { лет» }\end{array}$ & $\begin{array}{l}\text { Русь в середине } \\
12-\text { начале } 13 \text { веков. }\end{array}$ & $\begin{array}{l}\text { Россия - } \\
\text { многонациональная } \\
\text { страна }\end{array}$ \\
\hline 7 класс & $\begin{array}{l}\text { А.С. Пушкин } \\
\text { «Борис Годунов» }\end{array}$ & Смутное время & $\begin{array}{l}\text { Социальные ценности } \\
\text { и нормы }\end{array}$ \\
\hline 8 класс & $\begin{array}{l}\text { Пугачевский бунт в } \\
\text { «Капитанская } \\
\text { дочка» } \\
\text { А.С. Пушкина }\end{array}$ & $\begin{array}{l}\text { Правление Екатерины } \\
\text { Великой. Восстание } \\
\text { под предводительством } \\
\text { Емельяна Пугачева }\end{array}$ & $\begin{array}{l}\text { Права и свободы } \\
\text { гражданина } \\
\text { Российской Федерации }\end{array}$ \\
\hline 9 класс & $\begin{array}{l}\text { Биография } \\
\text { А.С. Грибоедова }\end{array}$ & $\begin{array}{l}\text { Правление Александра } \\
\text { Первого. Восстание } \\
\text { декабристов }\end{array}$ & $\begin{array}{l}\text { Формы государства. } \\
\text { Монархия и } \\
\text { республика - основные } \\
\text { формы правления. }\end{array}$ \\
\hline
\end{tabular}

В таблице 1 приведены самые очевидные примеры, и критики могут возразить, что полностью программу средней школы невозможно 
адаптировать к такому подходу. Да, это сложно. Но возможно, стоит только основательно взяться за этот процесс. Результаты не заставят себя ждать.

Во-первых, формирование гуманитарного урока приведет к повышению эффективности преподавания и более полноценному усвоению знаний по данным дисциплинам с демонстрацией практической значимости полученных знаний. Заинтересованность учащимися также повысится.

Во-вторых, сократится время, потраченное на изучение темы урока посредством сквозной подачи материала и объединения главных структур. Предмет исследования будет изучен глубже и полноценно.

В-третьих, внедрение данного подхода позволит сэкономить на кадровом составе, так как преподавать данный предмет будет один учитель вместо двух-трех.

В-четвертых, высвободятся бюджетные средства вследствие сокращения штата.

Как и в любой реформе, есть и риски. В частности, необходимо наладить процесс по переобучению преподавателей, проработать новые программы. Также могут возникнуть сложности у учащихся в случае смены учебного учреждения, если в нем еще не настроена данная программа.

\section{Список литературы}

1. Чумаков В.Ю. Русский след. История Нобелевской премии. - М.: ЭНАС-КНИГА, - 2020. - 328 с.

2. МП РФ ФГБНУ Институт стратегии развития образования Российской академии образования. Примерная рабочая программа основного общего образования. Литература (для 5-9 классов образовательных организаций). - М. $-2021 .-105$ с.

3. МП РФ ФГБНУ Институт стратегии развития образования Российской академии образования. Примерная рабочая программа основного общего образования. История (для 5-9 классов образовательных организаций). - M. $-2021 .-162 \mathrm{c}$.

4. МП РФ ФГБНУ Институт стратегии развития образования Российской академии образования. Примерная рабочая программа основного общего образования. Обществознание (для 6-9 классов образовательных организаций). - М. - 2021. - 109 с. 